\title{
Patent fixes for Europe
}

\section{The continent's patent system is Byzantine, but current proposals for a new EU-wide patent could make matters worse, warns Bruno van Pottelsberghe de la Potterie.}

$\mathrm{T}$ he European Union (EU) is a market of 500 million people. An efficient patent system for Europe would stimulate innovation in both new and existing firms and improve knowledge transfer from universities. A patent that is automatically valid Europe-wide could create a market for technology to rival that of the United States.

The current two-layer European patent system hinders the growth of creative institutions and ventures by being costly, inefficient and unpredictable. Patents granted by one layer, the European Patent Office (EPO), must actually be ratified in the second layer - the national level in one or several of the 27 EU countries. This makes a European patent five to twenty times more expensive than a US one, depending on the chosen geographical coverage, because of translation costs, multiple validation fees and yearly renewal fees that must be paid to each national patent office $(\mathrm{NPO})^{1}$ (see 'Costly European patents').

Parallel litigation regularly leads to conflicting outcomes in different countries, a degree of complexity and uncertainty that constitutes a serious barrier to start-up companies. And NPOs grant many patents independently of the EPO, including patents to foreign firms, which reduces overall quality and consistency in the system ${ }^{2}$.

The main obstacle to European patent reform for the past 50 years has been lack of political agreement on translation requirements. Finally, there are signs of progress at least on this point. But more fundamental reform is still required.

\section{LANGUAGE BARRIER}

In December 2009, the EU Competitiveness Council suggested the creation of a real EU patent valid all over Europe without further rubber stamps from the NPOs. Also proposed is a European and EU Patent Court to centralize patent-related litigation in Europe.In July this year, the European Commission (EC) proposed that EU patents should be examined and granted in one of English, French or German and the legal scope of protection of the granted patent - 'the claims' - translated into the other two languages ${ }^{3}$. Further translations would be required from the patent proprietor only in a legal dispute. The Spanish delegation proposed that the EPO grant all patents in English and one other EU language. The most innovation-friendly solution - English only - is not on the table, although nearly $80 \%$ of all patent applications

\section{COSTLY EUROPEAN PATENTS}

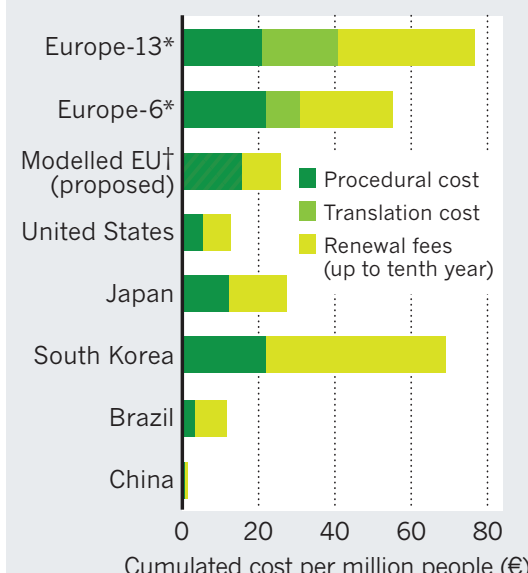

Cumulated cost per million people (€)

*Europe-13 (6) European patent validated in 13 (6) countries tmodelled (ref. 4)

to the EPO are filed in English ${ }^{3}$.

All this focus on languages is diverting attention from the fact that the EU patent proposals could result in a worse system than the current one. To really fuel innovation, the European ministers for economic affairs, industry and science who are preparing to meet at the EU Competitiveness Council later this year must fix the following issues, which are far more important than what gets translated into what.

Most alarmingly, the proposed EU patent would be a third layer atop the current European and national patents. Keeping the current patent systems in parallel with the

"There needs

to be a radical shake-up of the governance of the European patent system." new EU patent is likely to pave the way for yet more of the abusive legal behaviour practiced by some companies. For instance, a company could file for a national patent on minor improvements to an invention, made by itself or by another firm, that has already been granted a EU patent. The extra layer could lead to a greater amount of litigation in parallel, which would hold back small technology firms and universities even more.

Furthermore, as long as NPOs sit on the board of the EPO and are part of the working group that prepares proposals for the EU Competitiveness Council, there will be a conflict of interest. NPOs benefit from the national renewal fees paid for European patents ${ }^{4}$. Asking them to make proposals for an EU patent that would shrink their roles is like asking turkeys to vote for Thanksgiving.

\section{THE WAY FORWARD}

Here's what needs to happen instead. First, the current European patent should be phased-out by 2015 and be replaced by a true EU patent, recognized in all 27 countries at granting. NPOs should stop granting patents, but continue to process national priority filings (the first time a patent is filed, before it is transferred to the EPO), and perform searches for prior art.

Second, there should be a grace period of at least six months in which scientific or technical publications would not preclude patentability of an invention. The United States has a one-year grace period and Japan six months.

Third, there should be a $50 \%$ discount on EPO entry fees for young innovative companies, as in the United States and Japan. Up to now, the EPO's board has opted for a fee structure unfavourable to industrial minnows.

Fourth, there needs to be a radical shakeup of the governance of the European patent system. The number of NPO representatives on the EPO board should be reduced from the current 27 to around 10. Representatives of the key directorates of the EC should sit on the EPO board, representing stakeholder interests such as research, internal markets and competition policy.

Finally, it must be recognized that a good patent system is necessary, but not sufficient, for more innovation in Europe. Also essential are improving European universities' research performance, enhancing researchers' mobility within Europe and removing the many barriers to technology entrepreneurs, for instance by making access to capital markets easier ${ }^{5}$.

Bruno van Pottelsberghe de la Potterie is a professor at Université Libre de Bruxelles, 1050 Brussels, Belgium, and a senior fellow at the Brussels-based think-tank Bruegel. e-mail:bruno.vanpottelsberghe@ulb.ac.be

1. van Pottelsberghe de la Potterie, B. \& Mejer, M. Eur. J. Law Econ. 29, 211-237 (2010).

2. van Pottelsberghe, B. Bruegel Blueprint, Vol. IX (2009).

3. van Pottelsberghe, B. Bruegel Policy Brief 2010/02 (2010).

4. Danguy, J . \& van Pottelsberghe de la Potterie, B. ECARES Working Paper, 2010-012 (2010).

5. Dewatripont, M. et al. Bruegel Policy Contribution, 2010/06 (2010). 